ISSUES IN EUROPEAN BUSINESS 
Also by Peter Lawrence

Management Change in East Germany (with Vince Edwards) Management in the USA

French Management (with Jean-Louis Barsoux) 


\section{ISSUES IN EUROPEAN BUSINESS}

\section{Peter Lawrence}




\section{}

(C) Peter Lawrence 1998

All rights reserved. No reproduction, copy or transmission of this publication may be made without written permission.

No paragraph of this publication may be reproduced, copied or transmitted save with written permission or in accordance with the provisions of the Copyright, Designs and Patents Act 1988, or under the terms of any licence permitting limited copying issued by the Copyright Licensing Agency, 90 Tottenham Court Road, London W1P 9HE.

Any person who does any unauthorised act in relation to this publication may be liable to criminal prosecution and civil claims for damages.

The author has asserted his right to be identified as the author of this work in accordance with the Copyright, Designs and Patents Act 1988.

First published 1998 by

MACMILLAN PRESS LTD

Houndmills, Basingstoke, Hampshire RG21 6XS

and London

Companies and representatives

throughout the world

ISBN 978-0-333-68934-9 ISBN 978-1-349-26551-0 (eBook)

DOI 10.1007/978-1-349-26551-0

A catalogue record for this book is available from the British Library.

This book is printed on paper suitable for recycling and made from fully managed and sustained forest sources.

$\begin{array}{llllllllll}10 & 9 & 8 & 7 & 6 & 5 & 4 & 3 & 2 & 1\end{array}$

$\begin{array}{llllllllll}07 & 06 & 05 & 04 & 03 & 02 & 01 & 00 & 99 & 98\end{array}$ 
To my students at Loughborough University Business School 
'If you want clarity you cannot have faith, if you want truth you cannot have clarity.'

Søren Kirkegaard 


\section{Contents}

Acknowledgements

1 A thin red line

21992 and all that

3 Drink and diversity: the spirit of Europe 19

4 Patterns and forces 35

5 Strategy as a force field 47

6 Beyond the sea 61

7 Eastern Europe: patterns of the past $\quad 79$

8 Eastern Europe: a time of hope? 91

9 Eastern Europe: consequences and response 105

10 Patterns of diversity 119

11 European management 147

$\begin{array}{ll}\text { Index } & 163\end{array}$ 


\section{Acknowledgements}

This book draws on a number of research projects on which I have worked during the 1990s. First and foremost, I am a founder member of a multicountry research group known to its members as MODEM (Managers on Developing European Markets), formed in 1989. This group has been inspired and coordinated by academics from the Département de Politique Générale de l'Entreprise at ESC Lyon in Eastern France. The MODEM group carried out a study of executive's perceptions of the Single European Market, and later a study of the determinants of strategy among European companies. This second study was funded by the European Union. I have benefited greatly from involvement in these multicountry projects, and in particular from the quality of intellectual leadership offered by the French, who masterminded the research.

Since 1994 I have been a visiting professor at Nene College of Higher Education in Northampton. In this context I have been part of an ongoing study of the experiences of newly internationalising companies, a project I have worked on with Valerie Anderson, Stuart Graham and Kevin Lamb of Nene College, and more recently with Grahame Boocock, my colleague at the Loughborough University Business School. Nene College funded this project.

Also at Nene College, together with my friend Barbara Senior, I have carried out a questionnaire survey of the values and attitudes of managers from a variety of European and non-European countries. The data analysis was completed just in time to enable me to draw on some of the findings in Chapters 10 and 11 . This project too was funded by Nene College.

I would like to thank my MODEM colleague Murray Steele of the Cranfield School of Management for permission to use his case study on the European brewing industry. I would also like to thank my friend Vincent Edwards at Buckinghamshire College of Higher Education for permission to quote from his book Hungary since Communism (Macmillan, 1997), and from the Proceedings of the various CREEB (Centre for Research on Eastern European Business) conferences that he organised at Buckinghamshire College. 
Some of the ideas in Chapter 10 I was able to 'test run' in my inaugural lecture at Loughborough University Business School in February 1997, and was most heartened by the flattering things that people said at the time!

Finally I would like to thank Freda Clarke, my secretary at Loughborough University Business School, for a fast and friendly preparation of the manuscript and for cheerfully carrying out all sorts of assignments that have facilitated the work.

Peter Lawrence 